\begin{tabular}{lllllllll}
$\mathrm{A}$ & $\mathrm{R}$ & $\mathrm{T}$ & $\mathrm{I}$ & $\mathrm{C}$ & $\mathrm{L}$ & $\mathrm{E}$ & $\mathrm{S}$ \\
\hline
\end{tabular}

ROCZNIKI PSYCHOLOGICZNE/ANNALS OF PSYCHOLOGY

2020, XXIII, $1, \quad 7-21$

DOI: http://dx.doi.org/10.18290/rpsych20231-1

\author{
RAFAŁ P. BARTCZUK \\ JOANNA CHWASZCZ \\ STEVAN E. HOBFOLL ${ }^{b}$ \\ IWONA NIEWIADOMSKA ${ }^{\mathrm{a}}$ \\ MARIA GAŁKOWSKA-BACHANEK ${ }^{\mathrm{a}}$ \\ ${ }^{a}$ Institute of Psychology, John Paul II Catholic University of Lublin, Poland \\ ${ }^{b}$ STAR: Stress, Anxiety, and Resilience Consultants
}

\title{
IS THE STRUCTURE OF THE STRATEGIC APPROACH TO COPING SCALE CROSS-CULTURALLY STABLE? EVIDENCE BASED ON A SCOPING LITERATURE REVIEW
}

The Strategic Approach to Coping Scale (SACS) is a measure based on the Multiaxial Model of Coping. The original version of the scale consists of nine subscales, which form three second-order factors. An up-to-date review of SACS cultural adaptations was provided in order to examine the evidence for the cultural stability of SACS first- and second-level structures. The review demonstrated that among the SACS first-level factors some are more culturally stable and some are more sensitive to cultural context. The second-order structure of the SACS is more interculturally stable, especially the active-passive and social factors have a robust empirical justification.

Keywords: coping strategies; Multiaxial Model of Coping; Strategic Approach to Coping Scale.

Correspondence concerning this article should be addressed to RAFA£ P. BARTCZUK, PhD, Institute of Psychology, John Paul II Catholic University of Lublin, al. Racławickie 14 (room C-443), 20-950 Lublin, Poland; email: bartczuk@kul.pl; ORCID: https://orcid.org/0000-00020433-7327; JOANNA CHWASZCZ, ORCID: https://orcid.org/0000-0001-7068-4696; STEVAN E. HoBFOLL, ORCID: https://orcid.org/0000-0003-4136-0929; IwONA NIEWIADOMSKA, ORCID: https:// orcid.org/0000-0002-0244-2748. MARIA GAŁKOWSKA-BACHANEK, ORCID: https://orcid.org/00000002-1340-6398.

This research was partially supported by grant POKL.01.02.00-00-016/12-00 from the European Social Fund, awarded to the John Paul II Catholic University of Lublin Development Foundation, and realized under the direction of Joanna Chwaszcz. 


\section{INTRODUCTION}

The Multiaxial Model of Coping was developed by Stevan Hobfoll and colleagues (Dunahoo et al., 1998; Hobfoll et al., 1994; Monnier et al., 1998). It captures the social and cultural aspects of coping behaviors, which was missing in previous stress research. Originally, the model described coping behaviors on two axes: the conventional active-passive dimension and a prosocial-antisocial dimension (Hobfoll et al., 1994), not previously considered. Further research led to the extension of the model by a third axis, the direct-indirect dimension, reflecting intercultural differences in coping behaviors (Dunahoo et al., 1998; Hobfoll, 1998; Monnier et al., 1998). Currently, the Multiaxial Model of Coping consists of the three axes: active-passive, prosocial-antisocial and direct-indirect, representing dimensions of general coping strategies that permit a broader application across individualist and collectivist cultures than nearly all other models, which are based on individualistic cultural assumptions (Geller et al., 2009; Hobfoll et al., 2003).

Basically, the model assumes that active and avoidant strategies are not socially indifferent and ignoring this fact may lead to misinterpretation of their effects. Prosocial coping involves strategies based on a positive use of social resources. Antisocial coping includes behaviors that, while satisfying the individual's needs, can be detrimental to others. "Antisocial coping" does not denote psychopathological behaviors but ways of coping that are potentially harmful to others, consisting in using others or even exploiting them for personal gain (Monnier, Hobfol, \& Stone, 1996). The active-passive and prosocial-antisocial axes are not entirely orthogonal - the model does not predict passive prosocial strategies because being prosocial and passive at the same time is unlike as social activity assumes actions (Hobfoll, 1998; Hobfoll et al., 2003).

\section{THE STRATEGIC APPROACH TO COPING SCALE}

The Strategic Approach to Coping Scale (SACS) is a dedicated tool for measuring coping strategies according to the Multiaxial Model of Coping. At first, a preliminary version of the SACS (P-SACS) was developed based on the Dual-Axis Coping Model, consisting of 34 items containing responses that fit intuitively with the model. The P-SACS contained items generated on the basis of common proverbs, idioms, the literature on military and game strategies, and existing coping measures (Hobfoll et al., 1994). Participants responded to the 
P-SACS with reference to six hypothetical situations with varying stress severity (threat, loss, and failure to achieve goals), involving professional as well as interpersonal stressors. Using principal component analysis (PCA) and reliability analysis, the authors identified eight subscales in the SACS-P: (1) Assertive Action, (2) Social Joining, (3) Seeking Social Support, (4) Instinctive Action, (5) Avoidance, (6) Antisocial Action, (7) Aggressive Action, and (8) Cautious Action. To further explore an individualistic and communal way of coping, the authors added a third axis to the dual-axis model: direct-indirect coping (Dunahoo et al., 1998). After the model was so extended, the subscale of Indirect Action was added to the SACS (Dunahoo et al., 1998). The dispositional (SACS-D) and situational (SACS-S) versions of the scale were also developed (Monnier et al., 1998), each consisting of 52 items (Hobfoll, 1998).

To further examine whether the factors were consistent with the dual-axis model, second-order factor analyses were conducted. In the first study (Hobfoll et al., 1994) the authors tested two PCA solutions conducted on P-SACS subscales: a Kaiser criterion-based four-factor solution and a two-factor solution derived from the Dual-Axis Coping Model. The four-factor solution enabled the identification of: (1) Active-Passive Prosocial Coping, comprising Assertive Action, Social Joining, Seeking Social Support, and Cautious Action; (2) Active Asocial Coping, comprising Aggressive Action and Antisocial Action; (3) Passive Coping, comprising Assertive Action (taken reversely) and Avoidance; and (4) Active-Passive Asocial Coping, comprising Instinctive Action and Cautious Action. The two-factor solution revealed Active-Passive Prosocial Coping (Assertive Action, Social Joining, Seeking Social Support, and Cautious Action) and Active-Passive Antisocial Coping (Aggressive Action, Avoidance, Antisocial Action, and Instinctive Action). After extending the scale, the authors tested the multi-axial model of coping, employing PCA with varimax rotation and confirmatory factor analysis (CFA), conducted on SACS-D subscales in two separate samples (Dunahoo et al., 1998). In this way, three second-order factors were obtained: (1) Active Antisocial Coping, comprising Aggressive Action, Instinctive Action, and Antisocial Action; (2) Active Prosocial Coping, comprising Social Joining, Seeking Social Support, and Cautious Action; and (3) ActivePassive (asocial) Coping, constituted of Avoidance and Assertive Action (with the opposite sign). Indirect Action was loaded by Active Antisocial Coping factor in PCA, but it was included in Active-Passive in CFA (Dunahoo et al., 1998).

After the publication of the SACS, several translations and cultural adaptations of the scale were developed. The purpose of this article is to review these adaptations and assess the intercultural stability of the structure of the SACS. 


\section{REVIEW OF SACS CULTURAL ADAPTATIONS}

\section{Method}

For this scoping review, articles were identified by searching the PsycINFO database. The following search terms were used: ["Strategic Approach to Coping Scale" OR ("SACS" AND "Hobfoll")] AND ("adaptation"). PsycINFO was searched from its inception to February 11, 2019. Seventeen results were found. A publication was included in the analysis if it contained information on the structure of a culturally adapted version of the SACS, regardless of the type of source. Nine selected studies were supplemented with two SACS development studies (Dunahoo et al., 1998; Hobfoll et al., 1994) and two grey literature publications (Buchwald \& Lutz, 2006; Pérez \& Gómez-Maqueo, 2007) containing the desired information. Studies used in the review are listed in Table 1.

Table 1. Studies Included in the Review of SACS Cultural Adaptations

\begin{tabular}{|c|c|c|c|c|c|}
\hline Study & $\begin{array}{l}\text { Nation/ } \\
\text { Language }\end{array}$ & Sample & $\begin{array}{c}\text { SACS } \\
\text { version/ } \\
\text { No. of items }\end{array}$ & $\begin{array}{l}\text { 1st-level analysis } \\
\text { (method; result) }\end{array}$ & $\begin{array}{l}\text { 2nd-level analysis } \\
\text { (method; result) }\end{array}$ \\
\hline $\begin{array}{l}\text { Hobfoll et al., } \\
1994\end{array}$ & USA/eng & $\begin{array}{c}\text { Sample 1: } \\
\text { psychology students } \\
(n=204) \\
\text { Sample 2: } \\
\text { non-traditional } \\
\text { psychology students } \\
(n=184)\end{array}$ & $\begin{array}{l}\text { P-SACS } / 34 \\
\text { (in } 6 \text { hypo- } \\
\text { thetical } \\
\text { situations) }\end{array}$ & $\begin{array}{l}\text { PCA; } 9 \text { components } \\
\text { (2 of them combined } \\
\text { into one) }\end{array}$ & $\begin{array}{l}\text { PCA; } 4 \text { components } \\
\text { or } 2 \text { components }\end{array}$ \\
\hline $\begin{array}{l}\text { Dunahoo et al., } \\
1998\end{array}$ & USA/eng & $\begin{array}{c}\text { Sample 1: } \\
\text { students }(n=205) \\
\text { Sample 2: } \\
\text { significant others } \\
\text { of pregnant women } \\
\quad(n=105)\end{array}$ & SACS-D/49 & & PCA, CFA; 3 factors \\
\hline $\begin{array}{l}\text { Schwarzer, } \\
\text { Starke \& } \\
\text { Buchwald, } \\
2003\end{array}$ & GER/ger & $\begin{array}{l}\text { University students } \\
\qquad(n=930)\end{array}$ & $\mathrm{SACS}-\mathrm{D} / 52$ & PCA; 8 components & PCA; 4 components \\
\hline $\begin{array}{l}\text { Buchwald \& } \\
\text { Schwarzer, } \\
2003\end{array}$ & GER/ger & $\begin{array}{l}\text { Philosophy students } \\
\qquad(n=159)\end{array}$ & SACS-E/52 & PCA; 7 components & CFA; 3 factors \\
\hline
\end{tabular}


Pérez \&

Gómez-

Maqueo, 2007

Pérez,

Germán, \&

García, 2012

Roussi \&

Vassilaki,

2001

Roussi, Rapti

\& Kiosse-

oglou, 2006

Budău, Ciuca,

Miclea, \&

Albu, 2011

ROM/rom from universities, medical clinics, and various workplaces

$$
(n=105)
$$

Finklestein, Laufer, \& Solomon, 2012

Stapelberg \&

Wissing, 1999

RSA/tsn

?

Undergraduate

students $(n=251)$

2003

Buchwald \&

Lutz, 2006
ITA/ita

JAP/jap
High school students $(n=79)$
P-SACS/34

SACS-D/52;

SACS-S/52

$\mathrm{PCA}+\mathrm{RA}$

6 subscales

(Sample 1),

5 subscales

(Sample 2)

PCA; 3 components

SACS-D/52 EFA, CFA; 7 factors MDA; 3 dimensions

SACS-D/52 RA; 9 original

SACS-S/52 subscales assumed

PCA; 4 factors

(SACS-D), 3 factors

(SACS-S)

HCA on 7 subscales

$\mathrm{RA} ; 9$ original (excluded: Avoidsubscales assumed ance and Instinctive Action); 2 clusters

RA; 9 original subscales assumed

PCA; 3 components

CFA, PCA; original factors not confirmed, some factors reproduced

9 original subscales assumed

CFA; 3 factors

RA; 9 original subscales assumed

PCA; 4 components

Note. Abbreviations for countries: USA-United States, GER-Germany, MEX-Mexico, ESP-Spain, GRE-Greece, ROM-Romania, ISR-Israel, RSA-South Africa, ITA-Italy, JAP-Japan. Abbreviations for languages: eng-English, ger-German, esp-Spanish, gre-Greek, rom-Romanian, amh-Amharic, tsn-Setswana, ita - Italian, jap-Japanese. Abbreviations for SACS versions: P-SACS - preliminary, SACSD-dispositional, SACS-S - situational, SACS-E-exam situational. Abbreviations for statistical methods: PCA-Principal Component Analysis, CFA-Confirmatory Factor Analysis, RA-Reliability Analysis, EFA - Exploratory Factor Analysis, MDA-Multidimensional Scaling, HCA-Hierarchical Cluster Analysis, ?-data not available. 


\section{Results}

The SACS has been translated and adapted into a number of languages. However, despite our knowledge of numerous translations and adaptations, we know little about the intercultural stability of the SACS structure. A qualitative comparison of these adaptations is difficult, let alone quantitative one. As shown in Table 1, various versions of the scale were used in the studies (preliminary [P-SACS], dispositional [SACS-D], and situational [SACS-S]), the adaptation procedures used by researchers varied (including, or failing to include, an attempt to reproduce first- and/or second-level factors), as did data-analytical techniques.

Out of the 11 studies we analyzed, only four adaptations feature a full description of both stages. This is true for the German adaptation of the SACS-D (Schwarzer et al., 2003), the German adaptation of the SACS relevant to exam situations (Buchwald \& Schwarzer, 2003), and two adaptations of the SACS-D into Spanish: one from Mexico (Pérez \& Gómez-Maqueo, 2007) and the other from Spain (Pérez et al., 2012).

Another four studies contain only a second-order analysis of the subscales obtained based on the original scoring key: (1) two Greek studies of the SACS-D and SACS-S, where results of second-order groupings using PCA or hierarchical clustering (HCA) are presented in detail (Roussi et al., 2006; Roussi \& Vassilaki, 2001); (2) the Italian adaptation, where only fit indices for confirmatory factor analysis (CFA) second-order models for SACS-S and SACS-D were given (Comunian, 2003); and (3) the Romanian version, for which second-level PCA loadings are provided, but the analysis was carried out simultaneously using the results of SACS and another questionnaire (Budău et al., 2011).

In the case of the other three translations, scant data are available for either the first-order or second-order analysis. The South African Setswana language version authored by Stapelberg and Wissing in 1999 was mentioned in van Rooyen et al. (2000) and Wissing and Temane (2013). According to these sources, the SACS showed low reliabilities for the specific hypothesized strategies; CFA did not support the original factor pattern, but instead, a culturally unique factor pattern emerged, and some of the subscale names are reported. An Amharic adaptation of the SACS was translated from the Hebrew version (Finklestein et al., 2012), and only the summary of results of the first-level analysis is provided. As for the preliminary adaptation into Japanese (Buchwald $\&$ Lutz, 2006), only a summary of the second-order analysis is available. 
Other than those, there are several translations, not included in Table 1, for which we have only a confirmation of the reliability of the subscales, or information that the translation exists. This category includes Polish translations. Three Polish translations of the SACS can be found in the literature of the subject: (1) Zabielski and Polityńska's version, used in some research (e.g., Bernat \& Krzyszkowska, 2017; Losiak, 2008); (2) Kacmajor's translation of items from the Polish edition of Hobfoll's Stress, Culture, and Community (Hobfoll, 2006), used by some researchers (e.g., Chodak \& Barwiński, 2010); (3) the translation prepared at the Catholic University of Lublin by Niewiadomska's team, used in a number of studies (Chwaszcz et al., 2016; Jachowicz et al., 2015; Łącka et al., 2015; Niewiadomska et al., 2016; Pietras et al., 2015; Tyrka et al., 2015). All Polish translations have similar methodological statuses: only the reliability of the subscales based on the original scoring key is given in the publications.

Other translations of SACS include the Russian version, which has been substantially revised: it consists of 54 items, and each of the nine subscales has an equal number of items (Vodopianova, 2009). We have not been able to ascertain the methodology used to develop this form of the scale. However, it is commonly used in the countries of the former USSR (Banshchikova et al., 2019). A Hebrew translation of the measure, made by Westman, was found valid and reliable (Finklestein et al., 2012; Hobfoll, 1998, p. 207). Information on the Turkish adaptation of the SACS-D and SACS-S with nine original subscales made by Erktin in 1998 was reported by Ünal-Karagüven (2009). The Latvian adaptation (by Mika in 2002, as cited in Bite \& Martinsone, 2013; Plaude \& Raščevska, 2011) consists of nine subscales with names corresponding to the original ones. Moreover, in Latvia, Maslova (2016) translated the Russian adaptation of Vodopianova's version. Finally, one SACS subscale was translated into Swedish (Torkelson \& Muhonen, 2008).

\section{Replicability of the First-Level Structure}

Item grouping was carried out for six adaptations: both German adaptations, both Spanish, Amharic, and Setswana versions (see Table 2). The researchers obtained different numbers of factors, $8,7,5,7,9$, respectively (the number is unknown for Setswana). A comparison of factors obtained in the reviewed adaptations indicates that: (1) Seeking Social Support was identified in all the cases; (2) Avoidance was identified in most of the analyses (we do not know whether this factor was identified in the Setswana language); (3) Assertive Action and Instinctive Action were identified in four analyses (they were not obtained in the 
Amharic version, and the result for Setswana is unknown); (4) Social Joining was identified in three studies, while in two German versions it was merged with Cautious Action; (5) Indirect Action was also identified in three studies; (5) in four adaptations, Aggressive Action was combined into one factor with Antisocial Action, while Antisocial Action was identified as separate in the Setswana and Amharic cultures, and Aggressive Action only in Setswana; (6) Cautious Action only appeared in the Spanish analysis as an independent factor. Moreover, some studies revealed culturally specific factors such as Reflexivity (German), or Mastery, Self-Reliance, Individualism, and Passivity (Amharic).

Table 2. First-Order Structure Analyses of SACS in Cultural Adaptation Studies

\begin{tabular}{|c|c|c|c|c|c|c|}
\hline $\begin{array}{c}\text { Original } \\
\text { factors } \\
\text { (Dunahoo } \\
\text { et al., 1998) }\end{array}$ & $\begin{array}{c}\text { Schwarzer, } \\
\text { Starke, \& } \\
\text { Buchwald, } \\
2003 \\
\end{array}$ & $\begin{array}{c}\text { Buchwald \& } \\
\text { Schwarzer, } \\
2003\end{array}$ & $\begin{array}{c}\text { Pérez \& } \\
\text { Gómez- } \\
\text { Maqueo, } \\
2007\end{array}$ & $\begin{array}{l}\text { Pérez, } \\
\text { Germán, \& } \\
\text { García, } \\
2012\end{array}$ & $\begin{array}{l}\text { Finklestein } \\
\text { et al., } 2012\end{array}$ & $\begin{array}{c}\text { Stapelberg } \\
\text { \& Wissing, } \\
1999\end{array}$ \\
\hline $\begin{array}{c}\text { Aggressive } \\
\text { Action }\end{array}$ & $\begin{array}{c}\text { Aggressive- } \\
\text { Antisocial } \\
\text { Action }\end{array}$ & $\begin{array}{c}\text { Aggressive- } \\
\text { Antisocial } \\
\text { Action }\end{array}$ & $\begin{array}{l}\text { Aggressive- } \\
\text { Antisocial- } \\
\text { Indirect } \\
\text { Action }\end{array}$ & - & - & $\begin{array}{l}\text { Aggressive } \\
\text { Action }\end{array}$ \\
\hline $\begin{array}{l}\text { Antisocial } \\
\text { Action }\end{array}$ & $\begin{array}{c}\text { Aggressive- } \\
\text { Antisocial } \\
\text { Action }\end{array}$ & $\begin{array}{c}\text { Aggressive- } \\
\text { Antisocial } \\
\text { Action }\end{array}$ & $\begin{array}{l}\text { Aggressive- } \\
\text { Antisocial- } \\
\text { Indirect } \\
\text { Action }\end{array}$ & $\begin{array}{l}\text { Antisocial } \\
\text { Action }\end{array}$ & $\begin{array}{l}\text { Antisocial } \\
\text { Action }\end{array}$ & $\begin{array}{l}\text { Antisocial } \\
\text { Action }\end{array}$ \\
\hline $\begin{array}{l}\text { Instinctive } \\
\text { Action }\end{array}$ & $\begin{array}{l}\text { Intuitive } \\
\text { Action }\end{array}$ & $\begin{array}{l}\text { Intuitive } \\
\text { Action }\end{array}$ & $\begin{array}{l}\text { Instinctive } \\
\text { Action }\end{array}$ & $\begin{array}{l}\text { Instinctive } \\
\text { Action }\end{array}$ & - & $?$ \\
\hline $\begin{array}{l}\text { Cautious } \\
\text { Action }\end{array}$ & $\begin{array}{c}\text { Considerate } \\
\text { Action }\end{array}$ & $\begin{array}{c}\text { Considerate } \\
\text { Action }\end{array}$ & - & $\begin{array}{c}\text { Cautious } \\
\text { Action }\end{array}$ & - & $?$ \\
\hline $\begin{array}{l}\text { Social } \\
\text { Joining }\end{array}$ & $\begin{array}{c}\text { Considerate } \\
\text { Action }\end{array}$ & $\begin{array}{c}\text { Considerate } \\
\text { Action }\end{array}$ & - & $\begin{array}{l}\text { Social } \\
\text { Joining }\end{array}$ & $\begin{array}{l}\text { Social } \\
\text { Joining }\end{array}$ & $\begin{array}{l}\text { Social } \\
\text { Joining }\end{array}$ \\
\hline $\begin{array}{l}\text { Seeking } \\
\text { Social } \\
\text { Support }\end{array}$ & $\begin{array}{l}\text { Seeking } \\
\text { Social } \\
\text { Support }\end{array}$ & $\begin{array}{l}\text { Seeking } \\
\text { Social } \\
\text { Support }\end{array}$ & $\begin{array}{l}\text { Seeking } \\
\text { Social } \\
\text { Support }\end{array}$ & $\begin{array}{l}\text { Seeking } \\
\text { Social } \\
\text { Support }\end{array}$ & $\begin{array}{l}\text { Seeking Social } \\
\text { Support }\end{array}$ & $\begin{array}{l}\text { Seeking } \\
\text { Social } \\
\text { Support }\end{array}$ \\
\hline Avoidance & Avoidance & Avoidance & Avoidance & Avoidance & Avoidance & $?$ \\
\hline $\begin{array}{l}\text { Indirect } \\
\text { Action }\end{array}$ & $\begin{array}{l}\text { Indirect } \\
\text { Action }\end{array}$ & $\begin{array}{l}\text { Indirect } \\
\text { Action }\end{array}$ & $\begin{array}{l}\text { Aggressive- } \\
\text { Antisocial- } \\
\text { Indirect } \\
\text { Action }\end{array}$ & - & Indirect Action & $?$ \\
\hline $\begin{array}{l}\text { Assertive } \\
\text { Action }\end{array}$ & $\begin{array}{l}\text { Assertive } \\
\text { Action }\end{array}$ & $\begin{array}{l}\text { Assertive } \\
\text { Action }\end{array}$ & $\begin{array}{l}\text { Assertive } \\
\text { Action }\end{array}$ & $\begin{array}{l}\text { Assertive } \\
\text { Action }\end{array}$ & - & $?$ \\
\hline Other & $\begin{array}{l}\text { Reflexive } \\
\text { Action }\end{array}$ & & & & $\begin{array}{c}\text { Mastery } \\
\text { Self-Reliance } \\
\text { Individualism } \\
\text { Passivity } \\
\end{array}$ & $?$ \\
\hline
\end{tabular}


To summarize, the above results suggest that the first-level SACS structure varies across cultures, both in terms of the number and content of factors. At the same time, it is possible to identify factors that appear relatively stable across cultures (Seeking Social Support, Avoidance, Assertive Action, and Instinctive Action), and more culture-sensitive factors (Social Joining, Cautious Action, Indirect Action, Aggressive Action, and Antisocial Action). However, it should be noted that all the studies featured either Aggressive Action or Antisocial Action, or a common factor combining these subscales. Apart from cultural factors that may contribute to the diversity of results, attention must be paid to the fact that the original version of SACS was developed on the basis of a selfdescription of coping in six different stressful situations. This procedure was not reproduced in any of the adaptations. Moreover, not all studies relied on representative or well-stratified samples.

\section{Replicability of the Second-Level Structure}

The second-level structure was analyzed in nine studies (see Figure 1). Groupings were established using various methodologies, either based on the results of subscales obtained using the American scoring key (Greek, Romanian, and Italian adaptations), or on factors specific to cultures (German, Spanish, and Japanese). Because some studies describe second-order analyses in subgroups, in total, we have access to the results of five analyses conducted by Hobfoll's team at the SACS development stage and 11 cultural adaptation analyses. Concerning the adaptations, six analyses used PCA with varimax rotation, two used CFA, another two used HCA, and one used multidimensional scaling (MDS). The PCA of the Romanian version was carried out together with another measure of coping.

A review of analyses of second-level SACS structure revealed that: (1) in most analyses which included Assertive Action and Avoidance, they form a single, separate group-according to the multiaxial model, this is the ActivePassive axis; exceptions are the Mexican adaptation, in which Avoidance is associated with the antisocial dimension, and the Japanese version, in which, in turn, Assertive Action is associated with the antisocial factor. (2) According to the theoretical model, the remaining scales should be broken down into two groups: active-prosocial and active-antisocial. This is so in all the analyses based on original scoring - in Romania, Italy, and Greece. However, for adaptations based on culturally derived first-level factors, this result was obtained only in Japan and Mexico; in the others, they formed one group, such as prosocial-antisocial 


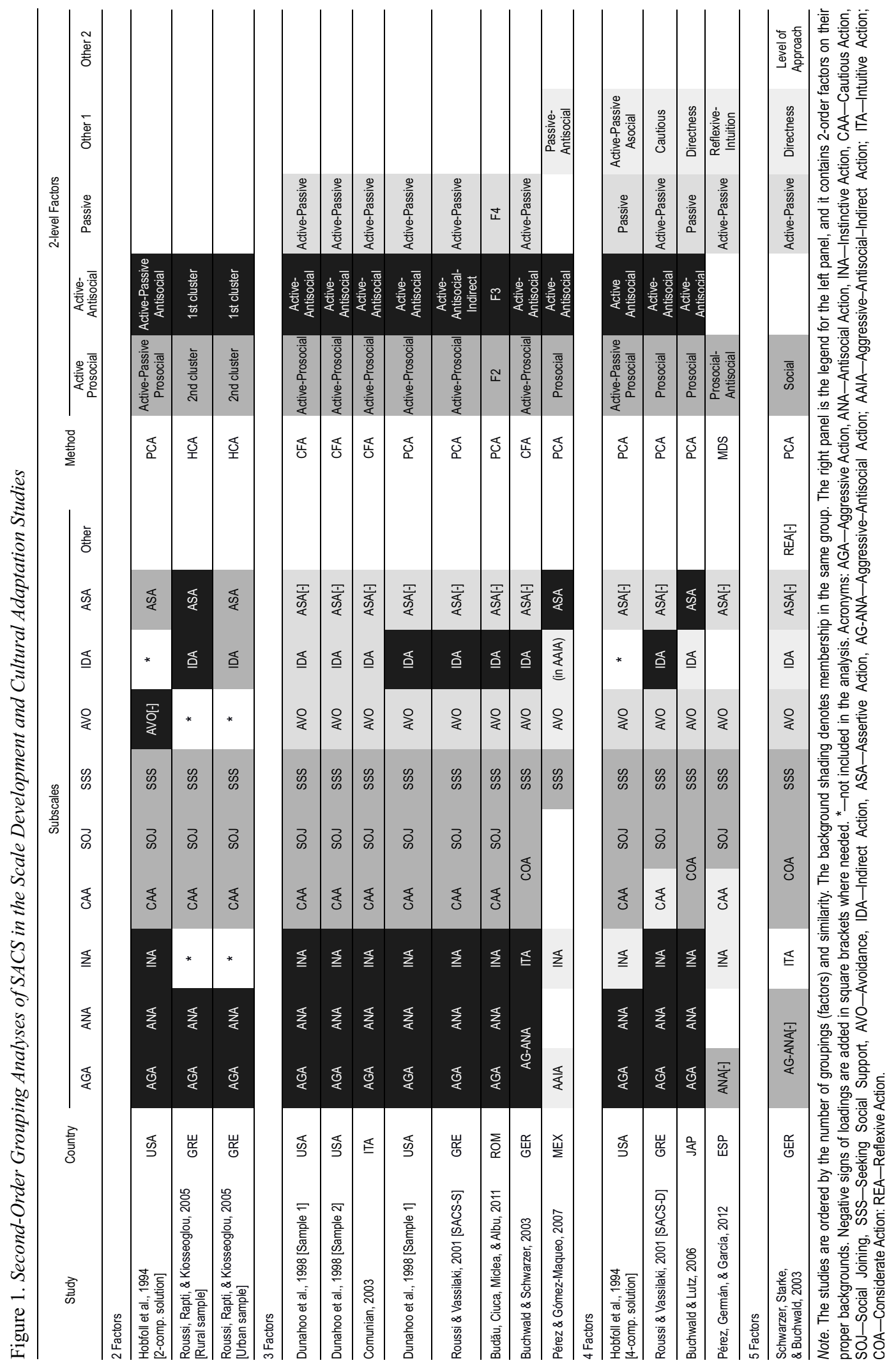


action (in Spain) or social dimension (in Germany) with Aggressive Action and Antisocial Action at one end, and Social Joining and Seeking Social Support at the other. (3) Cautious Action, Instinctive Action, and Indirect Action do not display a fixed affiliation, and were incorporated in different ways into activeprosocial or active-antisocial factors, or formed the basis of factors not provided for in the theoretical model, such as directness (in the German version) or reflective-intuitive dimension (in the Spanish version).

To summarize, based on Avoidance and Assertive Action, the identification of an active-passive factor should be primarily expected in the second-level SACS structure. With regard to social subscales, one can expect either two factors: active-prosocial (with Social Joining and Seeking Social Support) and active-antisocial (based on Aggressive Action and Antisocial Action), or one factor with two poles: prosocial (Social Joining and Seeking Social Support) vs. antisocial (Aggressive Action and Antisocial Action). Factors that in the first-order analysis turned out to be less interculturally stable also showed more considerable variation at the second level of analysis (not only between cultures but also between SACS versions and between urban and rural subpopulations). It seems reasonable to assume that they show a differentiation at both levels of the analysis, depending on the type of stressful situation and/or subpopulation.

\section{CONCLUSIONS}

The aim of our study was to provide an extensive review of the existing cultural adaptations of the SACS. Our conclusions apply to general issues related to the cultural adaptation of the SACS. Although there are numerous translations and adaptations of the scale, it should be noted that the available knowledge on the intercultural stability of the SACS structure is scant, mainly because reliable publications on the subject are lacking.

Few analyses of the SACS first-level structure are available. Instead, many authors rely on the original scoring key, assuming the first-level structure of the scale to be equivalent to the original, and only on the internal consistency coefficients. However, it is clear from the available studies that such a research principle is dubious because all adaptations in which first-order analysis was carried out showed divergence from the original. Our review suggests that among the SACS factors some are more culturally stable (Seeking Social Support, Avoidance, Assertive Action, Instinctive Action, as well as Antisocial Action and/or Aggressive Action) and some are more sensitive to the cultural context (Social 
Joining, Cautious Action, Indirect Action). Further research should help determine the extent of the cultural validity of Hobfoll's identified strategies in other cultures.

A critical methodological conclusion is a postulate that any structural analyses carried out should be thoroughly documented. Most of the SACS adaptations do not provide sufficient information to allow others to make independent interpretations - a problem common in reporting PCA/EFA practices in the early 2000s (Henson \& Roberts, 2006; Worthington \& Whittaker, 2006). It would be a good practice to report coefficients (at least a loadings matrix and proportion of the variance explained) to allow comparison of the results between cultures.

The second-order structure of SACS is more interculturally stable. The active-passive axis has a robust empirical justification. Regarding the social axis, one can expect either two factors: active-prosocial and active-antisocial, or one factor with two poles: (prosocial vs. antisocial). A resolution in this respect will require further research.

To date, there has been little empirical support that SACS is a good operationalization of the indirect-direct axis of coping. This is certainly due to the fact that adaptation research is carried out primarily in the countries of North America and Western Europe. Because this factor is assumed to be a derivative of cultural diversity in the individualism-collectivism dimension (Hobfoll, 1998), further research in highly collectivist cultures is required. Perhaps it would be reasonable to extend the scale with new coping strategies (cf. Hsu et al., 2008). The claim that some subscales/items need reformulation may be supported by the observation that in some cultures the content of the Indirect Action subscale (operationalization of indirectness by original assumption) is interpreted not as a tactful action but rather as manipulative and therefore antisocial.

Because of the cultural sensitivity of SACS there is a need for the Polish adaptation of the scale. It is an accurate measure to study coping with stress in the context of resource distribution. Based on the above review, we would expect that in the Polish version the number of first-level factors may differ from the original version and that the following factors will be revealed: Seeking Social Support, Avoidance, Assertive Action, Instinctive Action, and some form of Aggressive Action and/or Antisocial Action. On the second level, identification of the Active-Passive factor and either one or two social factors should be expected. For one factor its poles are set by prosocial strategies (Social Joining and Seeking Social Support) vs. antisocial ones (Aggressive Action and Antisocial Action). In the case of two social factors, the groups of active-prosocial and active-antisocial strategies would be correlated but distinct. 


\section{REFERENCES}

Banshchikova, T. N., Sokolovskii, M. L., Solomonov, V. A., \& Fomina, E. A. (2019). Psychometrics of the Russian version of the SACS instrument (S. E. Hobfoll's Strategic Approach to Coping Scale). Modern Journal of Language Teaching Methods, 9(1), 423-435.

Bernat, A., \& Krzyszkowska, M. (2017). Znaczenie i sposoby wykorzystania psychospołecznych zasobów zaradczych w ujęciu S. E. Hobfolla [Significance and ways od using psychosocial coping resources]. Studia Paradyskie, 27, 255-278.

Bite, I., \& Martinsone, B. (2013). Vardarbības seku pārvarēšana sievietēm grupu un individuālās psihoterapijas rezultātā piesaistes teorijas kontekstā [Overcoming the effects of violence on women as a result of group and individual psychotherapy in the context of attachment theory]. Latvijas Universitātes Raksti, 786, 21-36.

Buchwald, P., \& Lutz, S. (2006). Preliminary results of the Japanese adaptation to the Strategic Approach to Coping Scale [Poster]. 27. Internationalen Konferenz der Stress and Anxiety Research Society (STAR), University of Crete, Rethymnon. http://petra-buchwald.de/wpcontent/uploads/2018/01/Buchwald-P.-Lutz-S.-2006.-Preliminary-Results-of-the-JapaneseAdaptation-to-the-Strategic-Approach-to-Coping-Scale..pdf

Buchwald, P., \& Schwarzer, C. (2003). The exam-specific Strategic Approach to Coping Scale and interpersonal resources. Anxiety, Stress \& Coping, 16(3), 281-291. https://doi.org/10.1080/ 1061580031000095434

Budău, O., Ciuca, A., Miclea, M., \& Albu, M. (2011). The adaptation and validation process of the Romanian version of the Strategic Approach to Coping Scale (SACS). Cognitie, Creier, Comportament/Cognition, Brain, Behavior, 15(1), 131-141.

Chodak, M., \& Barwiński, Ł. (2010). Autoagresja jako forma radzenia sobie ze stresem-badania własne [Self-aggression as a form of coping with stress-A research report]. Psychiatria i Psychoterapia, 6(1), 31-46.

Chwaszcz, J., Wiechetek, M., \& Przybyłek, A. (2016). Coping strategies and the risk of developing Internet addiction in young people-A study report. In B. Lelonek \& J. Chwaszcz (Eds.), Gambling and Internet addictions-Epidemiology and treatment (pp. 101-107). Natanaleum Association Institute for Psychoprevention and Psychotherapy.

Dunahoo, C. L., Hobfoll, S. E., Monnier, J., Hulsizer, M. R., \& Johnson, R. (1998). There's more than rugged individualism in coping. Part 1: Even the Lone Ranger had Tonto. Anxiety, Stress, \& Coping, 11(2), 137-165. https://doi.org/10.1080/10615809808248309

Finklestein, M., Laufer, A., \& Solomon, Z. (2012). Coping strategies of Ethiopian immigrants in Israel: Association with PTSD and dissociation. Scandinavian Journal of Psychology, 53(6), 490-498. https://doi.org/10.1111/j.1467-9450.2012.00972.x

Geller, P. A., Hobfoll, S. E., \& Dunahoo, C. L. (2009). Women's coping: Communal versus individualistic orientation. In C. L. Cooper, J. C. Quick, \& M. Schabracq (Eds.), International handbook of work and health psychology (3rd ed., pp. 353-382). Wiley-Blackwell.

Henson, R. K., \& Roberts, J. K. (2006). Use of exploratory factor analysis in published research: Common errors and some comment on improved practice. Educational and Psychological Measurement, 66(3), 393-416. https://doi.org/10.1177/0013164405282485

Hobfoll, S. E. (1998). Stress, culture, and community: The psychology and philosophy of stress. Plenum Press. 
Hobfoll, S. E. (2006). Stres, kultura i spoteczność: Psychologia i filozofia stresu [Stress, culture and community: The psychology and philosophy of stress] (M. Kacmajor, Trans.). Gdańskie Wydawnictwo Psychologiczne.

Hobfoll, S. E., Dunahoo, C. L., Ben-Porath, Y., \& Monnier, J. (1994). Gender and coping: The dual-axis model of coping. American Journal of Community Psychology, 22(1), 49-82. https://doi.org/10.1007/BF02506817

Hobfoll, S. E., Geller, P., \& Dunahoo, C. L. (2003). Women's coping: Communal versus individualistic orientation. In M. Schabracq, J. A. M. Winnubst, \& C. L. Cooper (Eds.), The handbook of work and health psychology (2nd ed., pp. 237-257). J. Wiley \& Sons.

Hsu, W.-Y., Chen, M.-C., Wang, T.-H., \& Sun, S.-H. (2008). Coping strategies in Chinese social context. Asian Journal of Social Psychology, 11(2), 150-162. https://doi.org/10.1111/j.1467839X.2008.00252.x

Jachowicz, N., Niewiadomska, I., \& Bartczuk, R. (2015). Sense of support and stress coping strategies in nicotine-dependent persons. In J. Chwaszcz \& I. Niewiadomska (Eds.), Meaning of resources in social inclusion (pp. 80-90). Natanaleum Association Institute for Psychoprevention and Psychotherapy.

Łącka, I., Niewiadomska, I., \& Palacz-Chrisidis, A. (2015). Personality and stress coping strategies in gambling-addicted persons. In J. Chwaszcz \& I. Niewiadomska (Eds.), Meaning of resources in social inclusion (pp. 91-102). Natanaleum Association Institute for Psychoprevention and Psychotherapy.

Łosiak, W. (2008). Resource loss, coping, alcohol expectancies and drinking in students. Polish Psychological Bulletin, 39(3). https://doi.org/10.2478/v10059-008-0016-5

Maslova, J. (2016). The impact of pedagogical support program on coping strategies, academic achievement and stress level in adolescence. Society. Integration. Education. Proceedings of the International Scientific Conference, 2, 181-195. https://doi.org/10.17770/sie2016vol2.1397

Monnier, J., Hobfoll, S. E., Dunahoo, C. L., Hulsizer, M. R., \& Johnson, R. (1998). There's more than rugged individualism in coping. Part 2: Construct validity and further model testing. Anxiety, Stress, \& Coping, 11(3), 247-272. https://doi.org/10.1080/10615809808248314

Monnier, J., Hobfoll, S. E., \& Stone, B. K. (1996). Coping, resources, and social context. In W. Battmann \& S. Dutke (Eds.), Processes of the molar regulation of behavior (pp. 189-204). Pabst Science Publishers.

Niewiadomska, I., Jakimowicz, E., \& Augustynowicz, W. (2016). Adult Children of Divorce (ACOD)-Personal adjustment and preferred coping strategies. In I. Niewiadomska \& W. Augustynowicz (Eds.), Inclusion-Psychosocial aspects (pp. 44-56). Natanaelum Association Institute for Psychoprevention and Psychotherapy.

Pérez, E. J. P., Germán, M. Á. S., \& García, A. M. P. (2012). Adaptación española de la Escala Multiaxial de Afrontamiento Estratégico (SACS) de Hobfoll [Spanish adaptation of Hobfoll's Strategic Approach to Coping Scale], 24(3), 455-460.

Pérez, G. del C. V., \& Gómez-Maqueo, E. L. (2007). Resultados preliminares de la adaptacion al espanol de la Escala de Estrategias de Afrontamiento [Preliminary results of the Spanish adaptation of the Coping Scale]. Psicología y Salud, 17(2), 283-290.

Pietras, P., Niewiadomska, I., \& Palacz-Chrisidis, A. (2015). Personal adjustment and preferences for coping strategies in people with behavioural addictions. In J. Chwaszcz \& I. Niewiadomska (Eds.), Meaning of resources in social inclusion (pp. 103-113). Natanaleum Association Institute for Psychoprevention and Psychotherapy. 
Plaude, A., \& Raščevska, M. (2011). The association of cognitive abilities, emotional intelligence, defense mechanisms and coping with employment and unemployment. Baltic Journal of Psychology, 12(1-2), 83-101.

Roussi, P., Rapti, F., \& Kiosseoglou, G. (2006). Coping and psychological sense of community: An exploratory study of urban and rural areas in Greece. Anxiety, Stress, \& Coping, 19(2), 161-173. https://doi.org/10.1080/10615800600593304

Roussi, P., \& Vassilaki, E. (2001). The applicability of the Multiaxial Model of Coping to a Greek population. Anxiety, Stress, \& Coping, 14(2), 125-147. https://doi.org/10.1080/1061580010 8248351

Schwarzer, C., Starke, D., \& Buchwald, P. (2003). Towards a theory-based assessment of coping: The German adaptation of the Strategic Approach to Coping Scale. Anxiety, Stress \& Coping, 16(3), 271-280. https://doi.org/10.1080/1061580031000095425

Torkelson, E., \& Muhonen, T. (2008). Work stress, coping, and gender: Implications for health and well-being. In K. Näswall, J. Hellgren, \& M. Sverke (Eds.), The individual in the changing working life (pp. 311-327). Cambridge University Press. https://doi.org/10.1017/CBO97805 11490064.015

Tyrka, R., Niewiadomska, I., \& Bartczuk, R. (2015). The severity of crisis in valuation and the use of coping strategies in prison inmates. In J. Chwaszcz \& I. Niewiadomska (Eds.), Meaning of resources in social inclusion (pp. 80-90). Natanaleum Association Institute for Psychoprevention and Psychotherapy.

Ünal-Karagüven, M. H. (2009). Psychological impact of an economic crisis: A Conservation of Resources approach. International Journal of Stress Management, 16(3), 177-194. https://doi.org/10.1037/a0016840

Van Rooyen, J. M., Kruger, H. S., Huisman, H. W., Wissing, M. P., Margetts, B. M., Venter, C. S., \& Vorster, H. H. (2000). An epidemiological study of hypertension and its determinants in a population in transition: The THUSA study. Journal of Human Hypertension, 14(12), 779-787. https://doi.org/10.1038/sj.jhh.1001098

Vodopianova, N. E. (2009). Psikhodiagnostika stressa [Psychodiagnostics of stress]. Piter.

Wissing, M. P., \& Temane, Q. M. (2013). Feeling good, functioning well, and being true: Reflections on selected findings from the FORT research programme. In M. P. Wissing (Ed.), Well-Being Research in South Africa (pp. 225-250). Springer Netherlands. https://doi.org/10. 1007/978-94-007-6368-5_11

Worthington, R. L., \& Whittaker, T. A. (2006). Scale development research: A content analysis and recommendations for best practices. The Counseling Psychologist, 34(6), 806-838. https://doi.org/10.1177/0011000006288127 